\title{
The Court and the Legislators: Who Should Define the Scope of Free Movement in the $\mathbf{E U}$ ?
}

\author{
Martijn van den Brink
}

\section{Introduction}

Floris de Witte makes the case for free movement as the core of EU citizenship and offers three reasons in support. I agree with these principles, at least in the abstract. De Witte's vision certainly is normatively more appealing than the one of scholars who have pushed for a decoupling of EU citizenship from free movement. In fact, it is hard to see how EU citizenship cannot revolve to a very large extent around the right to move freely within the EU and to choose the preferred Member State of settlement. But if that is the case, de Witte seems to be asking the wrong question. What he seems to address is not the question of whether free movement should be defended, but how that should be done; through which procedures free movement is to be given shape.

\section{Free movement as the core of $E \mathbf{U}$ citizenship}

De Witte is concerned about the Dano decision and sees it as an attack on free movement. No doubt, the decision is a departure from earlier case law and signifies a move away from the very extensive interpretation of the free movement principles present in certain earlier decisions. Still, de Witte's opinion of the case as well as the way he uses the decision to support his claim is remarkable and not fully persuasive.

First, let's for a moment think about the difference EU citizenship has made. If one would have claimed in the mid-1990s, shortly after the introduction of EU citizenship, that in 2016 many EU lawyers have serious misgivings about a decision that denies social assistance benefits to an economically inactive EU citizen with very weak links to the Member State of residence, many would have been quite surprised about such a claim. The transformation brought about by EU citizenship has in that sense been remarkable. But was free movement not the core of EU citizenship before the Court started developing this concept in its case law? Of course it was. In fact, that so many lawyers thought EU citizenship to be a meaningless 
addition to the Treaties was precisely because it was largely premised on free movement. ${ }^{1}$

In other words, also post-Dano free movement remains the core of EU citizenship; it is simply that the precise contours of this right have changed somewhat. The real discussion thus is about the precise scope of the freedom to move and, relatedly, the principle of non-discrimination on grounds of nationality. The Treaty provisions on free movement are of course indeterminate and their meaning far from evident. Indeed, as de Witte suggests, the decision demonstrates that free movement is not unlimited, but whether this is a problem is something people will reasonably disagree about. This is also recognized by de Witte, who acknowledges that not everyone shares his belief that Dano is unjust.

\section{Justice, free movement, disagreement, and authority}

But it is at this point that the real issue arises, namely, how, in the face of disagreement about justice, such contestation is to be settled? Through which political procedures do we want to resolve such disagreements? What is necessary, in other words, is to 'complement one's theory of rights with a theory of authority'. ${ }^{2}$ This issue has been largely ignored by most discussions of the recent social assistance case law.

While not addressed explicitly, for de Witte the authority to settle such disputes is clearly to be given to the Court. This might be, as Bellamy in his reply submits, because de Witte's argument 'suggests that appropriate mechanisms do not exist for a constructive democratic dialogue that allows for a clear discussion of how we might balance reciprocity between citizenship regimes and reciprocity within them in an equitable and sustainable way'. However, while far from perfect, the EU has in fact adopted decisionmaking procedures that to the extent possible allow for such a dialogue. This dialogue, of course, takes place when the different institutions involved in the EU's legislative process, in which the EU citizen is represented by the national governments as well as by the European Parliament, deliberate and decide. These institutions have also spoken on many of the questions under-

1 Everson, M. (1995), 'The Legacy of the Market Citizen', in J. Shaw \& G. More (eds.), New legal dynamics of European Union, 73-90. Oxford: Clarendon Press.

2 Waldron, J. (1998), 'Participation: The Right of Rights', Proceedings of the Aristotelian Society New Series 98: 307, 322. 
lying the social assistance case law. They did so when the Citizenship Directive was adopted, in which the eligibility criteria for social assistance benefits for the economically inactive are laid down. The basic rule is that the economically inactive, such as students and jobseekers, are not entitled under EU law to benefits before they have acquired permanent residence. In Dano, but also a number of subsequent decisions, the Court deferred to these criteria.

I am uncertain on the basis of which grounds precisely de Witte objects to Dano, but it appears as if he suggests that the Court should have ignored the Citizenship Directive. After all, would Member States be obliged to give EU citizens like those in the position of Ms Dano social assistance benefits, it becomes increasingly difficult to see in what situations benefits can be denied to mobile Union citizens. Of course, de Witte might think this is what principles of justice require, but why the Court is the preferred institution to settle these issues, in particular when the legislator has spoken, he does not address. It simply does not suffice to claim that Dano is unjust, because it is precisely because there is disagreement about principles of justice that we need to decide who is to be given the authority to decide on these matters. The argument, which one often finds in the literature, that the Court should ensure that secondary law complies with primary law is not persuasive either. ${ }^{3}$ After all, the Treaty provisions are indeterminate, which raises the question why the Court's interpretation of them should be preferred over that of the legislator (also the Citizenship Directive is an interpretation of the relevant Treaty provisions). For de Witte's argument to work he would thus need to explain on what grounds he would want to leave those matters to the Court and not the legislator. In other words, if there is no obviously correct answer to the question of substance, to how the free movement provisions are to be interpreted, why should we, if we care about the law's democratic legitimacy, not answer the question of authority in favour of the legislator?

To put it differently, I am struggling to see how de Witte's Court-oriented perspective is compatible with his emphasis on the need 'to calibrate questions of justice and democracy in a more appropriate manner', because what he seems to suggest is that his preferred conception of justice is to be adopted by the Court against the wishes of the EU's legislator.

3 O'Leary, S. (2009), 'Equal Treatment and EU Citizens: A New Chapter on Cross-Border Educational Mobility and Access to Student Financial Assistance', European Law Review 34 (4): 612, 622. 


\section{How to defend free movement}

It is, for this reason, also that I think his suggestions might be counterproductive. To understand why, let's consider de Witte's objections against the 'emergency brake'. As a matter of principle I agree that this emergency brake is unnecessary and unjust. Whether the Court should also strike it down or interpret it away if it were ever adopted is a different matter. If de Witte believes that the boundaries of free movement set by the Citizenship Directive should have been ignored by the Court in Dano, he must also believe that the 'emergency brake' should be annulled. If, after all, the Member States should not be allowed to deny benefits to the economically inactive, he certainly must think that the Court should prevent benefits to be withheld from the economically active. Now, let's assume that the majority of the UK electorate had voted to remain part of the EU. Following the referendum, the Citizenship Directive would have been amended so as to include an emergency brake to give effect to the UK renegotiation. If the Court would decide to strike down these amendments large parts of the UK electorate would predictably be outraged and support for free movement would likely further erode.

The question thus also is how to defend free movement. If it is left to the Court alone to decide on the scope of the mobility rights of EU citizens, and certainly if that means disregarding legislative decisions, those who are hostile towards free movement are even less likely to support free movement. Problematically, absent support for free movement principles among EU citizens, this right will be difficult to sustain. I agree, therefore, with Rainer Bauböck's argument that the aim must be also to convince immobile Union citizens of EU citizenship's value.

Contrary to Bauböck, however, I am uncertain how this is to be achieved by working towards what Daniel Thym calls 'a vision of social justice for the Union as a whole'. Thym explains, correctly in my view, that 'free movement did not substitute national policy preferences with a supranational vision of social justice', but thinks that the Court should foster such a uniform supranational vision. With all respect, I think it would be highly problematic for the Court to do so, not only because such judicial behaviour is likely only to reinforce the backlash against the EU, but also because as Seyla Benhabib once explained with admirable clarity

'[s]ocioeconomic justice and criteria by which to examine it cannot be identified independently of democratic freedom and self-determination ... Precisely 
because there is no certainty on these matters even among experts, judgments as to who constitutes the "worst off" in society or in the world at large require complex democratic processes of opinion and will-formation'. ${ }^{4}$

On this issue Floris de Witte seems to agree. ${ }^{5}$ But it is precisely because of his emphasis on the importance of deciding issues of great normative salience through democratic processes that I struggle to understand his Court-centred perspective when what is at stake is the question from what moment in time mobile EU citizens are to be given full equal treatment. The EU's legislative process might be far from perfect in this regard, but it is comparatively superior, democratically speaking, to the judicial process. I think, therefore, that a plausible case can be made for the Dano decision from this angle. Furthermore, if our concern is to persuade those who are hostile towards free movement - if not of its value, then at least of the reasons why it should be respected - then defining the limits of free movement through the legislative process seems preferable. This at least allows us to explain to those who are sceptical of free movement that the rules in place were adopted on the basis of procedures in which their national governments were involved.

\section{Conclusion}

All of this does not change that I agree with de Witte that EU citizenship scholars should value free movement more than they tend to do. EU citizenship is not about the centralisation of rights and about replacing the democratically legitimated substance of national laws by uniform European ones. Instead, the value of EU citizenship lies in the opportunity it offers to EU citizens to take up residence in another Member State to pursue their dreams and ambitions. But while this is so, we should not forget that its value is not uniformly accepted by all Union citizens. Neither should we ignore that free movement never was meant to be unlimited. One may deplore this and criticise the status quo for being unjust, but that alone is insufficient to claim that the Court should change the scope of the free

4 Benhabib, S. (2004), The Rights of Others: Aliens, Residents and Citizens. Cambridge: CUP, 110-111.

5 See, de Witte, F. (2015), Justice in the EU: The Emergence of Transnational Solidarity. Oxford: OUP, 54. 
movement rights. To the contrary, if we want to defend the right to free movement and enlarge its support, respecting the legislative limitations might be the better way to go.

Open Access This chapter is licensed under the terms of the Creative Commons Attribution 4.0 International License (http://creativecommons.org/licenses/by/4.0/), which permits use, sharing, adaptation, distribution and reproduction in any medium or format, as long as you give appropriate credit to the original author(s) and the source, provide a link to the Creative Commons license and indicate if changes were made.

The images or other third party material in this chapter are included in the chapter's Creative Commons license, unless indicated otherwise in a credit line to the material. If material is not included in the chapter's Creative Commons license and your intended use is not permitted by statutory regulation or exceeds the permitted use, you will need to obtain permission directly from the copyright holder.

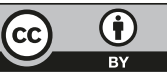

